\section{Effect of Sterol-demethylation Inhibiting Fungicides on Apple Fruit Set, Fruit Size, Total Yield, and Gross Returns}

\author{
D.A. Rosenberger \\ Department of Plant Pathology, New York State Agricultural Experiment \\ Station, Geneva, NY 14456
}

\section{T.L. Robinson and J.R. Schupp \\ Department of Horticultural Sciences, New York State Agricultural Experiment Station, Geneva, NY 14456}

C.A. Engle-Ahlers and F.W. Meyer

Department of Plant Pathology, New York State Agricultural Experiment Station, Geneva, NY 14456

Additional index words. captan, fenarimol, mancozeb, myclobutanil, triflumizole, Malus $\times$ domestica

\begin{abstract}
Effects of three sterol-demethylation inhibiting (DMI) fungicides and a contact fungicide were compared over two years at each of two locations to determine if fungicide treatments had differential effects on productivity, fruit size and shape, or gross returns for 'Empire' apples (Malus $\times$ domestica Borkh.). Treatments were applied four to five times per year during the primary apple scab season. Effects of treatments were assessed by comparing fruit set efficiencies, number of fruit per tree, total harvested fruit weight, and fruit length : diameter ratios at harvest. No significant differences were noted among individual treatments in any of the four trials. However, when treatments were contrasted by grouping individual treatments, significantly larger fruit size was noted for triflumizole treatments vs. combined fenarimol and myclobutanil treatments in one of the four trials and for captan or mancozeb compared to fenarimol and myclobutanil treatments in two trials. None of the DMI fungicides compared in these trials had any consistent adverse affect on fruit size, total yield, or estimated gross return per hectare. We conclude that the plant growth regulator effects of DMI fungicides are inconsistent and are unlikely to have significant economic impact on commercial apple production.
\end{abstract}

In the eastern United States, apple trees are usually sprayed with fungicides eight to 15 times per year to protect fruit and foliage from fungal diseases. The scientific literature contains numerous reports describing fungicide efficacy but only a few reports documenting non-target effects of older fungicides on the physiology or productivity of apple trees (Palmiter and Smock, 1954; Simon, 1986). Most of the described non-target effects of fungicides on apple trees are undesirable, bu the economic significance of these effects has not been evaluated for modern fungicides.

The sterol-demethylation inhibiting (DMI) fungicides were introduced in the 1980s, and three fungicides in this group (fenarimol, myclobutanil, triflumizole) are currently registered for controlling apple scab in the United States. After the DMI fungicides were introduced, nu-

Received for publication 27 Aug. 2002. Accepted for publication 3 Sept. 2002. Mention of a trademark, proprietary product, or vendor does not constitute a guarantee or warranty of the product by Cornell Univ. and does not imply its approval to the exclusion of other products or vendors that may also be suitable. merous researchers noted that these fungicides sometimes trigger responses in apple trees that are characteristic of plant growth regulators (PGRs). DMI fungicides have been reported to reduce return bloom (Biggs, 1990; Latham et al., 1985), reduce both ovule longevity and fruit set (Williams et al., 1987), increase fruit set (Church et al., 1984), have no effect on fruit set (Spotts and Cervantes, 1986), and reduce total yield of treated apple trees (Hutcheon et al., 1986; Lock and Andrews, 1986). DMI fungicides have also caused transient reductions in leaf transpiration (Biggs, 1990) and production of smaller, thicker leaves with multiple layers of palisade cells (Kelley and Jones, 1981).

Most reports concerning growth-regulator effects of fungicides involved test conditions that precluded assessments of economic impacts of the non-target effects. Studies in England documented that DMI fungicides applied between eight and 18 times per season reduced tree vigor (Lock and Andrews, 1986) and the period of viability of the ovules in flowers of 'Cox's Orange Pippin', thereby reducing fruit set (Hutcheon et al., 1986). However, apple growers in the United States generally use only three to six applications of
DMI fungicides per year. In other studies where DMI fungicides reduced return bloom and/or yield (Biggs, 1990; Latham et al., 1985), the authors did not report whether the observed effects were economically important. The interrelationship between fruit size and crop load was not adequately addressed in any of the earlier reports

The research reported here was initiated to determine if the PGR activity of DMI fungicides has an economic impact on fruit set, size, yield, and gross returns for 'Empire' apples. A secondary objective was to determine if, as implied by one manufacturer, trees treated with triflumizole would have larger fruit than trees treated with myclobutanil or fenarimol.

\section{Materials and Methods}

Similar fungicide treatments were evaluated during both the 1998 and 1999 growing seasons using 'Empire' orchards at the New York State Agricultural Experiment Station in Geneva, N.Y., and on a commercial farm near Clintondale, N.Y., in the Hudson Valley. Neither orchard had received any DMI fungicides during either the 1996 or 1997 season. In both locations, the same treatments were applied to the same trees in both years, except that only one rate of triflumizole was evaluated during the second year in the Hudson Valley. Fungicides included in comparisons were triflumizole (Procure 50W, Uniroyal Chemical Co., Middlebury, Conn.), fenarimol (Rubigan 1EC, Dow AgroSciences, Indianapolis), myclobutanil (Nova 40W, Rohm and Haas Co, Philadelphia), captan (Captec 4L; Micro Flo Co., Lakeland, Fla.), and mancozeb (Dithane 75DF, Rohm and Haas Co., or Penncozeb 75DF, Cerexagri, King of Prussia, Pa.).

Trials at Geneva, N.Y. The test orchard at Geneva contained trees planted in 1978 . The experimental design was a randomized complete block with five treatments and four replications. Two of the four replications were on M.26 rootstock, while the other two were on M.111 rootstocks with M.9 interstems. Each experimental plot had five to six test trees fully guarded by buffer trees. All sprays were applied at $3 \times$ concentration using an airblast sprayer delivering $935 \mathrm{~L} \cdot \mathrm{ha}^{-1}$. The calculated tree row volume of this orchard was $2805 \mathrm{~L} \cdot \mathrm{ha}^{-1}$. The test treatments in 1998 were applied on $21 \mathrm{Apr}$. (tight cluster to pink bud stage), 1 May (full bloom), 13 May (petal fall), and 27 May (first cover). In 1999, test treatments were applied 4 May (tight cluster), 11 May (pink), 20 May (full bloom), and 4 June (first cover). Mancozeb (Penncozeb 75DF, $5 \mathrm{~kg} \cdot \mathrm{ha}^{-1}$ a.i.) was applied 8 and 14 Apr. in 1998 and 26 Apr. in 1999 to all trees to protect against apple scab prior to the time of the first DMI applications. In 1998, all of the DMI fungicides in this test were tank-mixed with captan $\left(1682 \mathrm{~g} \cdot \mathrm{ha}^{-1}\right.$ a.i.) in each application and were compared to a treatment involving the same rate of captan used alone. In 1999, all of the DMI fungicides were tank-mixed with mancozeb (2522 $\mathrm{g} \cdot \mathrm{ha}^{-1}$ a.i.) and were compared to a treatment involving mancozeb alone applied at $5045 \mathrm{~g} \cdot \mathrm{ha}^{-1}$ a.i.. The entire block received 
six additional sprays of thiophanate-methyl (Topsin-M 70W, Cerexagri) in 1998 and three additional sprays of captan and thiophanatemethyl in 1999 to control summer diseases. Crop load was adjusted on 20 May 1998 by applying $1402 \mathrm{~L} \cdot \mathrm{ha}^{-1}$ of a solution containing $52 \mu \mathrm{g} \cdot \mathrm{L}^{-1}$ a.i. 6-benzyladenine (Accel, Valent Biosciences Corp., Libertyville, Ill.) and 0.6 $\mathrm{g} \cdot \mathrm{L}^{-1}$ a.i. carbaryl (Sevin XLR Plus 4L, Aventis Cropscience, Research Triangle Park, N.C.). On 28 May 1999, Accel at $78 \mu \mathrm{g} \cdot \mathrm{L}^{-1}$ a.i. and carbaryl at $0.6 \mathrm{~g} \cdot \mathrm{L}^{-1}$ a.i. were applied in 1402 $\mathrm{L} \cdot \mathrm{ha}^{-1}$ to adjust the crop load.

All fruit on each tree were harvested at maturity. Total fruit number and weight per tree were recorded and an arbitrarily selected 50 -fruit subsample was collected for each tree. The subsample was used to assess fruit size by passing the fruit over a computerized apple grader (MAF Industries, Traver, Calif.). A further subset of 20 randomly selected fruit was then analyzed for length : diameter ratio. Data were analyzed with the SAS General Linear Models procedure.

Gross returns were calculated as follows: The proportions of fruit in each size category were determined using the 50 -fruit subsamples from each plot. Multiplying the total number of fruit per plot by the number of plots per hectare provided an estimate of the productivity per hectare expressed as number of fruit per hectare. Multiplying the proportion of fruit in each size category by the calculated number of fruit per hectare provided an estimate of yields per hectare for each fruit size category. Average size and pricing relationships for 'Empire' fruit during the 1997-98 marketing season were provided by local apple growers and were used to calculate the estimated gross returns per hectare based on the fruit size distribution observed in each test plot.

Trials at Clintondale, N.Y. The test orchard was planted in 1991 with trees on MM.111 rootstocks with M.9 interstems. Treatments were replicated four times using three-tree plots. All test plots were located in a single row through the center of the orchard, and test treatments were superimposed on the normal mancozeb fungicide program that the cooperating grower used to control apple scab. The DMI fungicides were applied at the perhectare rate commonly used by commercial growers, whereas mancozeb (Dithane 75DF) included in the test treatments was applied at $0.84 \mathrm{~kg} \cdot \mathrm{ha}^{-1}$ a.i., a rate appropriate for the calculated tree-row volume of $1000 \mathrm{~L} \cdot \mathrm{ha}^{-1}$ in this orchard.

Treatments were applied using a handgun operating at $10^{3} \mathrm{kPa}$. Handgun applications were timed with a stopwatch to ensure precise applications of the designated rate per hectare for each of the test treatments. All treatments were applied in the equivalent of $467 \mathrm{~L} \cdot \mathrm{ha}^{-1}$ of spray solution. Applications in 1998 were made on 7 Apr. (early tight cluster bud stage), 14 Apr. (pink), 23 Apr. (early bloom), 6 May (petal fall), and 14 May. Treatments in 1999 were applied on $19 \mathrm{Apr}$. (tight cluster), $28 \mathrm{Apr}$. (pink), 14 May (petal fall), and 28 May.

Effects of treatments on natural fruit set were determined on 12 May 1998, about a week after petal fall, by counting the number of pollinated fruitlets on 50 clusters per tree. Counts were made by evaluating the first 50 clusters on a given scaffold limb, starting from the most distal portion of the limb. The portion of the limb used for the initial fruit-set count was marked with flagging tape, and the count was repeated on 27 July to determine if fungicide treatments affected the response to NAA applied by the grower to adjust crop load. In 1999, the number of clusters on marked branches was counted on 7 May and the number of fruit on these same branches was counted on 15 June, after final fruit set was established. The grower applied NAA (Fruitone N, Amvac Chemical Corp., Newport Beach, Calif.), at 7.5 $\mathrm{mg} \cdot \mathrm{L}^{-1}$ a.i. on 16 May 1998 and 20 May 1999 to adjust crop load.

Effects of treatments on fruit number, fruit weight, and total yield per tree were evaluated by harvesting, counting, and weighing all fruit from each of two trees per replicate on 14 Sept. 1998 and on 20 Sept. 1999 at the same time that the grower was harvesting adjoining rows. Subsamples for evaluation of individual fruit size were collected from all three trees in each replicate on 14 Sept. 1998 and 15 Sept. 1999. In 1998, subsamples were collected by harvesting the first eight fruit encountered on the most distal portion of each of three arbitrarily selected scaffold limbs on the east side of each tree. In 1999, subsamples consisted of 10 similarly selected fruit from three arbitrarily selected scaffold limbs around the perimeter of the tree. Subsamples were held in cold storage at $1{ }^{\circ} \mathrm{C}$ until the samples could be evaluated. The storage period was 8-10 d in 1998 and 1-2 d in 1999. Fruit from each subsample were individually weighed. Thus, the fruit size distribution for each tree was determined based on a 24- (1998) or 30- (1999) fruit subsample. Economic analyses were performed as previously described.

\section{Results}

Individual fungicide treatments had no significant effect $(P \leq 0.05)$ on either total yield measured in kilograms per tree or the number

Table 1. Effect of fungicides on fruit size of 'Empire' apples and crop load of treated trees.

\begin{tabular}{|c|c|c|c|c|c|c|c|c|}
\hline \multirow{3}{*}{$\begin{array}{l}\text { Treatment and rate } \\
\left(\mathrm{g} \cdot \mathrm{ha}^{-1} \text { a.i. }\right)\end{array}$} & \multicolumn{4}{|c|}{ Fruit size $(\mathrm{g})$} & \multicolumn{4}{|c|}{$\begin{array}{l}\text { No. fruit } / \mathrm{cm}^{2} \\
\text { trunk cross-sectional area }\end{array}$} \\
\hline & \multicolumn{2}{|c|}{ Geneva } & \multicolumn{2}{|c|}{ Clintondale } & \multicolumn{2}{|c|}{ Geneva } & \multicolumn{2}{|c|}{ Clintondale } \\
\hline & 1998 & 1999 & 1998 & 1999 & 1998 & 1999 & 1998 & 1999 \\
\hline Triflumizole (280) & 185 & 187 & 172.4 & 142.4 & 1.9 & 2.4 & 6.8 & 12.0 \\
\hline Triflumizole (210) & 182 & 187 & 175.0 & n.d. ${ }^{z}$ & 1.9 & 2.3 & 5.8 & n.d. ${ }^{\mathrm{z}}$ \\
\hline Myclobutanil (140) & 181 & 183 & 164.6 & 149.8 & 2.2 & 2.6 & 7.4 & 9.3 \\
\hline Fenarimol (70) & 179 & 181 & 163.4 & 138.8 & 2.0 & 2.9 & 7.7 & 11.4 \\
\hline Captan or mancozeb ${ }^{y}$ & 188 & 191 & 169.5 & 145.6 & 1.8 & 2.1 & 6.8 & 12.1 \\
\hline$P$ values from ANOVA & 0.25 & 0.11 & 0.08 & 0.18 & 0.63 & 0.50 & 0.19 & 0.13 \\
\hline \multicolumn{9}{|l|}{ Contrasts ( $P$ values $)$} \\
\hline Triflumizole vs. myc/fen ${ }^{x}$ & 0.24 & 0.44 & 0.004 & 0.70 & 0.30 & 0.33 & 0.06 & 0.27 \\
\hline Triflumizole vs. capt/manc ${ }^{y}$ & 0.16 & 0.03 & 0.23 & 0.58 & 0.60 & 0.37 & 0.49 & 0.93 \\
\hline Myc/fen vs. capt/manc & 0.03 & 0.01 & 0.13 & 0.80 & 0.20 & 0.12 & 0.34 & 0.24 \\
\hline All DMIs vs. capt/manc & 0.06 & 0.01 & 0.84 & 0.68 & 0.32 & 0.18 & 0.88 & 0.38 \\
\hline
\end{tabular}

${ }^{\mathrm{z}}$ n.d. = no data. Treatment not included in the 1999 trial.

${ }^{y}$ Capt/manc: Captan (1687 g.ha ${ }^{-1}$ a.i.) was used in the 1998 trial at Geneva, N.Y. Mancozeb (5045 g.ha ${ }^{-1}$ a.i.) was used at in the 1999 trial at Geneva. Mancozeb $\left(841 \mathrm{~g} \cdot \mathrm{ha}^{-1}\right.$ a.i. $)$ was used in both years at Clintondale, N.Y.

${ }^{\mathrm{x}} \mathrm{Myc} / \mathrm{fen}=$ grouped myclobutanil and fenarimol treatments. of fruit per tree in any of the four field trials (two years $\times$ two locations). Furthermore, the individual treatments also showed no effects on fruit size or crop load where the latter was defined as the number of fruit $/ \mathrm{cm}^{2}$ of trunk cross-sectional area (Table 1).

Contrasts between various fungicide groups showed that there were no differences in either year for fruit number per tree, yield per tree, or yield efficiency ( $\mathrm{kg}$ fruit $/ \mathrm{cm}^{2}$ of trunk crosssectional area) between triflumizole and the combined myclobutanil and fenarimol (myc/ fen) treatments, or between triflumizole and the captan or mancozeb treatment (data not shown)-nor were there any differences in crop load per tree in the analyses of grouped treatments (Table 1). However, the myc/fen group had significantly smaller fruit size than the captan or mancozeb treatment during both years at Geneva, and the myc/fen group had smaller fruit than the triflumazole group in the 1998 trial at Clintondale (Table 1). There was also a significant reduction in fruit size when all the DMI treatments together were contrasted with the mancozeb treatment at Geneva in 1999.

When the fungicide treatments applied at Clintondale were compared individually, there were no significant differences in fruit set in either of the two years $(P=0.12$ in $1998 ; P=0.79$ in 1999). However, when the two triflumizole treatments and the mancozeb treatment were grouped together and compared to the myc/fen group in 1998, mean fruit set as measured on 27 July was significantly $(P=0.01)$ higher for the myc/fen group (Table 2). Similar treatment groupings and comparisons in 1999 showed no significant differences $(P=0.83$, data not shown). The lack of differences in fruit set or fruit size between any of the grouped treatments in 1999 showed that the increased fruit set on in 1998 did not reduce return bloom in 1999.

None of the individual treatments had a significant effect on fruit length/diameter (L: D) ratios in any of the four trials (Table 3). However, when grouped treatments were contrasted, the L:D ratios were very slightly, but significantly, smaller for the myc/fen group trees treated with myclobutanil and fenarimol 
Table 2. Comparison of fenarimol and myclobutanil treatments vs. triflumizole and mancozeb treatments for their effects on fruit set, total yield, and fruit size at Clintondale, N.Y., 1998.

\begin{tabular}{|c|c|c|c|c|}
\hline \multirow[b]{2}{*}{ Treatment grouping } & \multicolumn{2}{|c|}{ Mean no. } & \multirow{2}{*}{$\begin{array}{l}\text { Total wt } \\
\text { fruit/tree } \\
(\mathrm{kg})\end{array}$} & \multirow{2}{*}{$\begin{array}{l}\text { Mean } \\
\text { individual } \\
\text { fruit wt }(\mathrm{g})\end{array}$} \\
\hline & $\begin{array}{c}\text { Fruit/cluster } \\
27 \text { July }\end{array}$ & Fruit/tree & & \\
\hline Triflumizole and mancozeb treatments & $0.25 \mathrm{a}$ & $267 \mathrm{a}$ & $45.9 \mathrm{a}$ & $172 \mathrm{~b}$ \\
\hline Myclobutanil and fenarimol treatments & $0.40 \mathrm{~b}$ & $305 \mathrm{a}$ & $50.2 \mathrm{a}$ & $164 \mathrm{a}$ \\
\hline$P$ values from data analysis & 0.010 & 0.099 & 0.264 & 0.007 \\
\hline
\end{tabular}

Table 3. Effect of fungicides on fruit length : diameter ratios of 'Empire' apples.

\begin{tabular}{|c|c|c|c|c|}
\hline \multirow{3}{*}{$\begin{array}{l}\text { Treatment and rate } \\
\left(\mathrm{g} \cdot \mathrm{ha}^{-1} \text { a.i. }\right)\end{array}$} & \multicolumn{4}{|c|}{ Fruit length : diameter ratio } \\
\hline & \multicolumn{2}{|c|}{ Geneva } & \multicolumn{2}{|c|}{ Clintondale } \\
\hline & 1998 & 1999 & 1998 & 1999 \\
\hline Triflumizole (280) & 0.87 & 0.88 & 0.81 & 0.84 \\
\hline Triflumizole (210) & 0.87 & 0.89 & 0.81 & n.d. ${ }^{\mathrm{z}}$ \\
\hline Myclobutanil (140) & 0.86 & 0.89 & 0.81 & 0.84 \\
\hline Fenarimol (70) & 0.87 & 0.88 & 0.80 & 0.84 \\
\hline Captan or mancozeb ${ }^{y}$ & 0.88 & 0.90 & 0.82 & 0.84 \\
\hline$P$ values from ANOVA & 0.25 & 0.26 & 0.21 & 0.75 \\
\hline \multicolumn{5}{|l|}{ Contrasts ( $P$ values) } \\
\hline Triflumizole vs. myc/fen ${ }^{x}$ & 0.91 & 0.69 & 0.15 & 0.88 \\
\hline Triflumizole vs. capt/manc ${ }^{y}$ & 0.12 & 0.06 & 0.30 & 0.36 \\
\hline Myc/Fen vs. capt/manc & 0.11 & 0.04 & 0.04 & 0.36 \\
\hline All DMIs vs. capt/manc & 0.09 & 0.04 & 0.09 & 0.31 \\
\hline
\end{tabular}

than for the mancozeb treatment in two of the four trials (Table 3 ).

Gross value of the crop was estimated for each treatment using fruit size distributions as determined from subsamples and applied to the total number of fruit per tree using size-pricing relationships (Table 4). Fungicide treatments did not significantly affect the estimated dollar-value of the crop in either year or either location (Table 5). Estimated crop value per hectare, assuming no defects and a $100 \%$ pack-out, ranged from $\$ 24,142$ to $\$ 41,142$. The higher mean value for treatments at $\mathrm{Ge}$ neva as compared to Clintondale was due to higher tree densities at Geneva that resulted in greater yield per hectare despite a lower crop load per trunk cross-sectional area.

\section{Discussion}

This is the first study to evaluate the economic impacts of PGR effects of fungicides on apples over multiple years. At Clintondale, 'Empire' fruit from trees treated with triflumizole in 1998 were slightly (7.8-11.6 g) larger than fruit from trees treated with myclobutanil or fenarimol, but those differ- ences did not re-occur in 1999. Also, fruit set efficiency rated on 27 July 1998 showed that more fruit were retained on trees treated with fenarimol or myclobutanil than on trees with other treatments. The inconsistent effects on fruit size or shape in our studies contrast with those of Sugar et al. (2000), who noted significant effects of DMI fungicides on the shape of 'Bartlett' pears.

The lack of consistent effects of fungicides on fruit set and fruit size may be related to differences in the timing of fungicide and fruit thinning applications at the two sites and over was applied $2 \mathrm{~d}$ after a fungicide application at treatment was applied $6 \mathrm{~d}$ after a fungicide application. At Geneva, fruit thinning sprays were applied more than $7 \mathrm{~d}$ after fungicide treatments in both years. Rosenberger et al. (1999) reported that tebuconazole, another DMI fungicide, also interfered with fruit thinning when it was applied close to a carbaryl thinning spray. In that trial, 'Ginger Gold' trees treated with tebuconazole $3 \mathrm{~d}$ before carbaryl was applied as a thinner retained significantly more fruit than similar trees treated with trithe two years of the experiment. In 1998, NAA Clintondale, whereas in 1999 the NAA thinning flumizole, whereas fruit set with myclobutanil was intermediate and not significantly different from either triflumizole or tebuconazole. If myclobutanil and fenarimol have weak and transient PGR effects that interfere with fruit thinning sprays, these might have contributed to the fruit set differences noted at Clintondale in 1998. At the Geneva location and the other test year at Clintondale, the PGR effects of the fungicides might have dissipated before the thinning sprays were applied. Thus, even when DMI fungicides have some PGR activity, that activity may only become apparent when the fungicide interacts with fruit thinners applied at or near the same time.

DMIs belong to a class of triazole compounds that have been evaluated as both fungicides and PGRs (Greene, 1986). DMI compounds were selected for inhibitory activity of sterol biosynthesis in fungi, whereas paclobutrazol (PB) and similar compounds were selected for inhibitory activity of plant gibberellin biosynthesis. However, the DMI fungicides and PB sometimes produce similar non-target effects (Buchenauer, 1995). The increased fruit set (Table 2) and flattened fruit shape (Table 3 ) resulting from DMI treatments in our studies are side effects also reported for PB (Curry and Williams, 1983; Greene, 1986; Steffens et al., 1985). It is thought that the PGRlike activity of DMI fungicides is caused by inhibition of plant sterol biosynthesis, not by inhibition of gibberellin synthesis (Benveniste and Rahier, 1992). However, the effects of the DMI fungicides used in this study on plant sterol synthesis are not well documented.

The limited and inconsistent PGR effects of DMI fungicides observed in this trial contrast sharply with the pattern established for PB. Greene (1986) showed that the effects of PB on fruit L:D ratio and pedicel length persisted for 3 years. We observed mild effects of increased fruit set and reduced fruit size in Clintondale in 1998 when myclobutanil and fenarimol were applied shortly before thinning sprays, but there were no significant effects on fruit set on those same trees the next year. Nor were there any effects on fruit set at the Geneva site where the DMI sprays were not applied close to thinning sprays. Thus, PGR effect of DMI fungicides seem to be more transient than those documented for PB.

None of the DMI fungicides compared in these trials had any consistent adverse affect on fruit size, total yield, or estimated gross return per hectare. This study provides some indication that any effects of myclobutanil and
Table 4. Size categories and prices used to calculate gross returns for 'Empire' fruit.

\begin{tabular}{cc}
\hline $\begin{array}{l}\text { Individual } \\
\text { fruit wt }(\mathrm{g})\end{array}$ & $\begin{array}{c}\text { Market price } \\
\text { cents } / \mathrm{kg}\end{array}$ \\
\hline$<77.8($ culls $)$ & 8.8 \\
$77.8-110.7$ & 55.1 \\
$110.8-133.4$ & 59.4 \\
$133.5-151.8$ & 69.5 \\
$151.9-190.1$ & 98.9 \\
$190.2-224.1$ & 98.4 \\
$>224.1$ & 85.4 \\
\hline
\end{tabular}

Table 5. Effect of fungicides on gross returns (\$/ha) of 'Empire' apples.

\begin{tabular}{|c|c|c|c|c|}
\hline \multirow{2}{*}{$\begin{array}{l}\text { Treatment and rate } \\
\left(\mathrm{g} \cdot \mathrm{ha}^{-1} \text { a.i. }\right)\end{array}$} & \multicolumn{2}{|c|}{ Geneva } & \multicolumn{2}{|c|}{ Clintondale } \\
\hline & 1998 & 1999 & 1998 & 1999 \\
\hline Triflumizole (280) & 32,748 & 36,746 & 28,273 & 39,160 \\
\hline Triflumizole (210) & 33,702 & 39,336 & 24,142 & n.d. ${ }^{z}$ \\
\hline Myclobutanil (140) & 36,709 & 41,142 & 27,791 & 32,817 \\
\hline Fenarimol $(70)$ & 30,905 & 39,724 & 27,539 & 28,409 \\
\hline Captan or mancozeb ${ }^{y}$ & 31,681 & 32,644 & 25,160 & 36,385 \\
\hline$P$ value from ANOVA & 0.46 & 0.88 & 0.70 & 0.37 \\
\hline
\end{tabular}

${ }^{{ }^{z}}$.d. = no data. Treatment not included in the 1999 trial.

${ }^{y}$ capt/manc: Captan (1687 g.ha ${ }^{-1}$ a.i.) was used in the 1998 trial at Geneva, N.Y. Mancozeb (5045 $\mathrm{g} \cdot \mathrm{ha}^{-1}$ a.i.) was used at in the 1999 trial at Geneva. Mancozeb (841 $\mathrm{g} \cdot \mathrm{ha}^{-1}$ a.i.) was used in both years at Clintondale, N.Y. 
fenarimol on fruit size may be attributable to the heavier crop load that results when fruit set is increased. The DMI fungicides might increase fruit set when applied just prior to thinning sprays, but additional work is needed to explore the interactions of myclobutanil and fenarimol with thinning sprays. We conclude that the plant growth regulator effects of DMI fungicides are inconsistent and are unlikely to have significant economic impact on commercial apple production.

\section{Literature Cited}

Benveniste, H. and A. Rahier. 1992. Target sites of sterol biosynthesis inhibitors in plants, p. 207226. In: W. Koller (ed.). Target sites of fungicide action. CRC Press, Boca Raton, Fla.

Biggs, A.R. 1990. Reduction in transpiration and return bloom in apple by two sterol-inhibiting fungicides. HortScience 25:1403-1405.

Buchenauer,H. 1995. DMI-fungicides-Side effects on the plant and problems with resistance, $\mathrm{p}$. 259-290. In: H. Lyr (ed.). Modern selective fungicides, 2nd ed. Verlag, Jena, Germany.

Church, R.M., L. Copas, and R.R. Williams. 1984 Changes in fruit set, leaf size, and shoot growth of apple caused by some fungicides, insecticides, and a plant growth regulator. J. Hort. Sci. 59: 161-164.

Curry, E.A. and M.W. Williams. 1983. Promalin or $\mathrm{GA}_{3}$ increase pedicel and fruit length and leaf size of 'Delicious' apples treated with paclobutrazol. HortScience 18:214-215.

Greene, D.W. 1986. Effect of paclobutrazol and analogs on growth, yield, fruit quality, and storage potential of 'Delicious' apples. J. Amer. Soc. Hort. Sci. 111:328-332.

Hutcheon, J.A., J. Coyle, M.E. Holgate, and R.J.W. Byrde. 1986. Effects of fungicide on long-term cropping and fruit quality of apple. Plant Pathol. 35:249-253.

Kelley, R.D. and A.L. Jones. 1981. Evaluation of two triazole fungicides for postinfection control of apple scab. Phytopath. 71:737-742.

Latham, A.J., W.A. Dozier, Jr., J.W. Knowles, and M.H. Hollingsworth. 1985. Suppression of apple bloom by fungicides that inhibit sterol biosynthesis. Plant Dis. 69:776-778.

Lock, T. and L. Andrews. 1986. Effects of fungicides on powdery mildew, tree growth, and cropping of apples. Plant Pathol. 35:241-248.

Palmiter, D.H. and R.M. Smock. 1954. Effect of fungicides on McIntosh apple yield and quality: A five-year study under Hudson Valley conditions, 1949-1953. N.Y. State Agr. Expt. Sta. Bul. 767:40

Rosenberger, D.A., F.W. Meyer, and C.A. Engle. 1999. Controlling diseases on Jerseymac and Ginger Gold apple trees with contact and DMI fungicides, 1998. Fungic. Nematicide Tests 54 : $18-19$.

Simon, P.J. 1986. Effects of some fungicides on cell membrane permeability in apple. Med. Fac. Landbouww. Rijksuniv. Gent 51:459-463.

Spotts, R.A. and L.A. Cervantes. 1986. Effects of fungicides that inhibit ergosterol biosynthesis on apple powdery mildew control, yield, and fruit growth factors. Plant Dis. 70:305-306.

Steffens, G L., S.Y. Wang, M. Faust, and J.K. Byun. 1985. Growth, carbohydrate, and mineral element status of shoot and spur leaves and fruit of 'Spartan' apple trees treated with paclobutrazol. J. Amer. Soc. Hort. Sci. 110:850-855.

Sugar, D., R.A. Spotts, W.D. Gubler, and G.T. McGourty. 2000. Effect of fenarimol application timing on fruit shape of Bartlett pear. Plant Dis. 84:182-184.

Williams, R.R., D.V. Child, L. Copas, and M.E. Holgate. 1987. The mechanism of yield suppression by a triadimefon fungicide programme on the apple cv. Cox's Orange Pippin. J. Hort. Sci. 62:291-294. 